\title{
The Changes of Hungarian Security Policy Preferences in the First Years of World War II (1938-1941)
}

\author{
Lajos Olasz
}

Department of Applied Social Sciences and Minority Policy, University of Szeged, Hungary

Copyright $\bigcirc 2017$ by authors, all rights reserved. Authors agree that this article remains permanently open access under the terms of the Creative Commons Attribution License 4.0 International License

\begin{abstract}
Between the two World Wars, the relationship towards the neighbouring countries determined the main aspects of the Hungarian security policy. After World War I, huge areas and more than 3 million Hungarian inhabitants were detached from Hungary and annexed to the neighbouring countries. Hungarian politics mostly took efforts to re-annex these territories, what highly increased pressure with the neighbouring Czechoslovakia, Romania, and Yugoslavia. After the outburst of World War II, the relationship with the two expansive world-powers, Germany and the Soviet Union got more emphasis. In the eyes of the Hungarian government, Berlin simultaneously represented a threat and a support to re-annex the detached territories. During the period of the outburst of the World War, the Hungarian political elite maintained its viewpoint focusing mainly on the territorial disputes going on with the neighbouring states. In theory, it evaluated the potential risks threatening the country well. In practice, however, it rather only drifted with the events and made narrow-minded decisions that did not consider wider perspective.
\end{abstract}

Keywords History of Hungary, Central Europe, Security Policy, Territorial Revision, Armed Neutrality, World War II

\section{Introduction}

The peace system that finished World War I winded up the Austrian-Hungarian Monarchy and squeezed German and Russian presence out from Central and Eastern Europe. In this area, from the Baltic to the Balkans, a zone consisting of small states got created, with 12 new countries or countries with substantially transformed territories. While the stability of the area was built earlier on the balance between the world-powers, between the two wars it was built on the vacuum of the world-powers. The buffer zone countries established between the German and Russian (later Soviet) territories had double geopolitical function. They kept
Europe far from bolshevism ("cordon sanitaire" role), while by co-operating with the Western Powers, they tried to limit the German expansion efforts. This is what ensured stability for the continent's eastern half. However, it could have been realised successfully only by using a significant Western economic and political support, but this did not happen [1].

Between the two World Wars, it enhanced the problems of Central and Eastern Europe that the mostly artificially established new states and the $12,800 \mathrm{~km}$ long new borderline often drawn without any historical antecedents generated serious territorial and ethnic conflicts among the countries. Destruction of the former organic economic and social units and the unlimited enforcement of the strategic interests of the winners and their allies only added new conflicts to the former ones existing among the nations. The rivalling small states were not able to establish an effective collaboration system based on the consent of common security in Central and Eastern Europe and the Western Powers did not regard it important enough. They did not recognise it in time that the region being under double external pressure and getting gradually destabilised as a result of considerable internal disagreements could easily become the victim of the reviviscent German, then Soviet expansion [2].

This was the geopolitical space where Hungary created its own security policy. One of the most important aspects was revision, i.e. the intent to regain the Hungarian territories that had been detached after World War I (the Trianon Peace Treaty). The effort of making revisions involved not only a few fields of the security policy, but all of its important elements. The military security, the development of military force and the establishment of borders that could be protected well were closely related to the revision. The Hungarian foreign policy steps were primarily determined by the effort of making revisions. They wanted to strengthen economic security by regaining the resources located on the detached territories. In the field of domestic political stability, the effort to make revisions also got an important role in making the existing system legitimate. This was supported by a wide range of the society, even by the extreme right wing opposition. Such a specific definiteness of the 
Hungarian security policy kept on being valid even in the period of the outburst of World War II. However, there were significant changes in its practical implementation [3].

\section{Between the Two World Wars}

Between the two World Wars, the Hungarian security policy was considering a double perspective. Its strained relationship towards the neighbouring states determined its primary aspect. The peace treaty of Trianon that finished World War I cut the Kingdom of Hungary into pieces. 67\% of its territory, including also regions where Hungarians lived in majority, was annexed to the neighbouring countries. As a result, 3.2 million Hungarian inhabitants got under Czechoslovakian, Romanian and Southern Slavonic control. Since that time, the main target of the Hungarian politics had been to change, to revise the peace treaty, so that at least it could regain the territories where Hungarians lived. Naturally, Czechoslovakia, Romania and the Kingdom of Serbia-Croatia-Slovenia wanted to hinder it by any means. By 1921, the three states under the name of "Little Entente" unfolded an economic, political, and military collaboration that mainly focused on making the implementation of revision impossible [4].

The peace treaty made Hungary fully vulnerable militarily to the Little Entente states. They limited the number of people of the Hungarian military force (up to 35000 soldiers) and prohibited to keep modern weapons (aircraft, tanks, heavy artillery), while the Little Entente had eight times bigger force. In addition, Budapest and the most significant Hungarian cities, the economic centres were situated directly along the borders, what meant that the military forces of the Little Entente could smite them seriously within the first few hours of an outbursting clash of arms [5].

A wider horizon in the Hungarian security policy was represented by shaping the relationship towards the field of force of power which had been being unfolded after World War I. In order to implement a successful revision, there were allies needed. From among the Western Powers, Hungary was mainly seeking contact with Great-Britain. Hungary could not find any common political platform with France, the chief patron of the Little Entente. Later on, even the British government itself expressed certain critic on the peace treaties conducted after World War I. The Hungarian moderate, conservative political circles made endeavours to have amicable revision via negotiations. They hoped to captivate British politics to achieve that a more equitable and reasonable territory rearrangement would take place. However, London made efforts to maintain the status quo and it did not support any endeavours to change the borders, including any Hungarian territorial demands [6].

As a result of the rejection got from the Western Powers, the Hungarian politics changed its orientation towards Italy and Poland. Hungary had old, historic relationship with both states and both countries were interested in changing the balance of forces in Central Europe. Co-operation provided opportunity to Hungary to break through the ring of the Little Entente. At the same time, it was also essential for both states to avoid the quickly strengthening German political influence. The Hungarian government entered into a treaty of friendship with Italy in 1927, while with Poland in 1928. However, the Polish connections were only very loose, while Italy was more and more clearly played down by the second half of the 1930-ies by the Germans who wanted to gain control over Central and Eastern Europe [7].

Germany's influence gradually got stronger during the 1930-ies. It became more and more important economic partner of the Central and Eastern European states. In 1936, during the remilitarisation of the Rhineland and other events, it turned out that even the Western states cautiously related themselves to the German politics: they already regarded the Third Reich as a world-power. Adolf Hitler made it unambiguous that forces and interests bonded him to the Eastern region and he intended to use an active foreign policy in this area. How relationships with Germany had changed was also affected by the fact that a considerable number of German minorities lived in Central and Eastern Europe which served as a point of reference for Berlin to the extension of its influence. The Hungarian constitutional system and the moderate conservative politics were far from the German national socialist dictatorship, and Hitler's plan of war. The widening economic relationships, the presence of the German minority of approx. 450,000 people, as well as the hope that Berlin would support the efforts made towards revisions made even the Hungarian government approach towards Germany [8].

The relationship with the other totalitarian power of the area, with the Soviet Union was characterised by holding cold distance. The Hungarian political elite got into power at the end of World War I, after the failure of a Bolshevik revolution, and had harsh anti-Communist sentiments. In 1934, diplomatic relations were established with the Soviet Union, and the commercial turnover gradually increased. However, Budapest kept on regarding Stalin's politics as a potential source of risk. Hungary was not the direct neighbour of the Soviet territories because Czechoslovakia and Romania separated it from them. Until the outburst of World War II, the Soviet geopolitics did not show substantial interest towards the Carpathian Basin. Moscow invariably followed the traditional Russian foreign affairs political strategy and turned towards the Baltic countries and the South-East parts of the Balkans with more focused attention. Consequently, Hungary was jeopardized not by the expansion intents of the Soviet Union, but by the dissemination of communist ideas [9].

As far as the Little Entente states are concerned, the Hungarian government followed a different policy. It regarded Czechoslovakia as the most dangerous opponent. Along the Czechoslovakian border, a Hungarian minority of approx. 850000 people lived, relatively in one block. This represented a good reference base for revisions for Hungary, 
while from the point of view of Prague it was ground for serious fear. That was why it was the Czechoslovakian government that undertook the most active anti-Hungarian politics. The Czechoslovakian military force was the most cutting edge one in the area. In 1935, Prague entered into a military aid treaty with France and with the Soviet Union. With this (especially with the involvement of the Soviets), Prague significantly overinsured itself, what already did not increase its security, but only intensified suspicion at its neighbours. The Hungarian government's attitude towards Romania was rather reserved. However, in the case of Yugoslavia there were several trials for approach. This was due to the facts that Hungary had close historic connection with Southern Slavonic peoples, and that after the Trianon Treaty relatively few Hungarian territories and only 500,000 Hungarian inhabitants got under the supremacy of the Southern Slavonic state [10].

For the Hungarian security policy, the first more considerable shock was the "Anschluss", the fusion of Germany and Austria in March 1938. On 12 March, upon the request of the Austrian extreme right wing raised to power by huge German support, German troops entered Austria. In Hungary, this event initiated serious political unease from two aspects. The extremist forces being raised to power with German collaboration replaced the constitutional system with a totalitarian political system within a few weeks. This highly stimulated the radical political entities of other Central and Eastern European countries, including the Hungarian extreme right wing opposition to put the conservative government under higher pressure than earlier. On the other hand, during the Anschluss, Hitler emphasised that he was only making efforts to unite all the territories with German speaking inhabitants. However, in the western and southern counties of Hungary there was a big German minority living, what could easily provide legal basis (or rather excuse) to an expansive world-power to potentially claim even Hungarian territories later on [11].

The Anschluss led to serious social anxiety. Therefore, Regent Miklós Horthy had to make a speech via the radio to the inhabitants of the country to reassure them that the country's independence and parliamentary setup were not jeopardized. The regent had spoken never before via the radio. Several prime ministers had already used this propaganda tool, but Horthy - following the Hungarian kings' ruling traditions - did not regard it necessary to talk to the people directly. However, due to the threatening closeness of the German empire appearing at the western borders he had to take this step [12].

After Austria's annexation, Hitler claimed territories even from Czechoslovakia, namely the country's western region where really mostly German minority lived, the Sudeten area. Detaching this territory would have deprived Czechoslovakia from essential resources, developed industrial area, and well set up border protection. With this, Czechoslovakia would have become vulnerable to further German claims. As a reply to the German pressure, the
Prague government ordered mobilisation on 21 May. On the next day even the Western Powers warned Germany that Great-Britain and France would not watch it passively if Czechoslovakia was attacked. According to the German military leadership the military force was not in a suitable state to undertake an armed attack either, but Hitler had already the intention to obtain the selected territory [13].

In this situation, the German diplomacy tried to involve Hungary in the conflict, too. They tried to persuade the Hungarian political and military circles that Regent Horthy took military steps to get back the detached territories. Intensive negotiations had started, Wilhelm Keitel artillery general, the head of Wermacht, then Wilhelm Canaris vice-admiral, the head of the German military intelligence service visited Budapest, while Hermann Göring general field-marshal, air minister tried to convince the Hungarian government through the Hungarian ambassador in Berlin. In return, they even offered an option to re-annex the entire Slovakia. If Hungary had attacked Czechoslovakia first, Germany could have interfered in the created conflict with a much lower risk [14].

In August 1938, Hitler invited the Hungarian regent to take a personal visit. He was received with royal splendour amidst of huge celebrations, and grandiose externalities. Horthy and the members of the government definitely insisted on revision, but they wanted to implement it preferably amicably via negotiations. They made efforts to capture Germany's support, but they also regarded it important to have the approval of the West so that both European power centres acknowledged the re-annexation of the Hungarian inhabited territories on a longer term. That was why they did not agree to take the role of the "agent provocateur" to burst out a conflict that could again cover the whole of Europe with war. They recognised that although the existing Central European status quo was extremely disadvantageous for Hungary, its forced changing would have also jeopardized seriously the Hungarian interests. Therefore, Regent Horthy rejected the option of military action [15].

The Czechoslovakian conflict represented a serious security policy problem to the Hungarian government. Despite its will, Hungary might drift in a war taking place in the neighbouring country, while the Hungarian Army had not been prepared. Participation in this conflict could have easily triggered the intervention of the other two Little Entente states. That was why Hungary first had to secure its borders and avoid a potential Romanian or Yugoslavian action via an agreement. After a longer preparatory period, during August, negotiations were initiated between the Little Entente and the Hungarian government in Bled, Yugoslavia. According to the treaty signed on 22 August, the neighbouring states accepted Hungary's equal rights to arm. Yugoslavia and Romania envisaged the improvement of the situation of the Hungarian minority that had been living on their territory. The negotiating parties declared that they mutually waived of the forced redefinition of the borders [16]. 
This treaty increased Hungary's space of motion in foreign politics. The Little Entente countries recognised the right of the Hungarian state to represent the interests of the Hungarian minority living on their territories. The German leadership sharply criticised the treaty of Bled. They concluded that Hungary let down Berlin and practically dissociated itself from the German-Czechoslovakian conflict. The treaty was also received well by the Western Powers, especially after the Anschluss and the May Czechoslovakian crisis, because they hoped that it could help to restore stability in Central and Eastern Europe. The world press mostly appreciated the mutual back-down from applying force. The newspapers welcomed the treaty that Hungary and the Little Entente were reconciled and the situation in Central Europe got back to normal with this. The Hungarian press interpreted the treaty in a way that Germany was not against it either, since Berlin had been urging Hungary for several years already to try to settle its relationship with its neighbours [17].

\section{The First Steps of Territorial Revision}

The Hungarian politics that chose the way of conflict management through negotiations and the Czechoslovakian general mobilisation ordered on 20 September led Germany to try to enforce its territorial claims concerning Czechoslovakia by way of negotiations instead of a military solution. The Western Powers were also ready to assist to settle it amicably. In Munich, on 29 September, 1938, a four-power conference was convened, where the leaders of the German, Italian, French, and British governments made a decision that the Sudeten area that had German inhabitants had to be re-annexed to Germany. With this, Great-Britain and France hoped to restrain German expansion on a longer term. However, Germany interpreted the West's passivity as a signal of weakness and kept on planning further expansive steps. Czechoslovakia - considerably weakened by transferring the German-inhabited region - did not even want to hear about the transfer of any more territories, so made its borders stronger even militarily towards Poland and Hungary [18].

The Munich conference had not made a respective decision about the Hungarian-Czechoslovakian territorial debates. The world-powers recommended bilateral negotiations to the involved parties. At the negotiations started in October 1938, Czechoslovakia was already represented by the autonomous Slovakian provincial government that only approved few minor border adjustments. The negotiations ceased and both parties mobilised its army. There were several border incidents, too. At the territory of Subcarpathia real bush-fighting had unfolded between the Czechoslovakian forces and the non-regular paramilitary organisation ("Ragged Guards") penetrating through the Hungarian border. Finally, in order to avoid war, both governments requested arbitration from the world-powers. Since neither Great-Britain, nor France wanted to collaborate in redefining the Central and Eastern European borders, the two disputing parties requested Germany and Italy to come to a decision. The First Vienna Award made on 2 November, 1938 re-annexed a 12,000 km² territory to Hungary, with approximately 1.1 million inhabitants, $84 \%$ of which had Hungarian as his or her mother tongue [19].

However, neither the Hungarian, nor the Czechoslovakian politics was satisfied with the award. The Hungarian party lacked the re-annexation of several cities, while the Subcarpathia and Czechoslovakian parties considered the detached territories way too big and requested the return of at least $5000 \mathrm{~km}^{2}$. Consequently, the tension between the two countries did not get lower after the territorial decisions. The Hungarian party regarded it especially threatening that during the autumn the Prague government considered to ask for Soviet military aid. In September, Soviet officers arrived in Czechoslovakia to prepare the arrival of the Red Army troops. One day before the Munich Conference, the military commissar informed Stalin about the fact that if Prague requested it, they were able to send 550 military airplanes to Czechoslovakia immediately. All in all, the Czechoslovakian government did not undertake any armed opposition. However, the opportunity that Soviet military force might appear along the Hungarian borders made the Hungarian government extremely frustrated [20].

Budapest did not incline to give up its claim concerning Subcarpathia. The leadership of the Hungarian Army urged for military entry. With this, they would have broken through the ring of the Little Entente, i.e. the country's enclosed situation would have been released. The Hungarian-Polish common border would have represented reliable protection against the Soviet Union. Germany rejected the Hungarian ideas; therefore the Hungarian government requested political support from Italy. It turned out, however, that it was not an option to rely on Rome against Hitler. Consequently, the action planned to get back Subcarpathia was postponed for a while [21].

At the beginning of 1939, various groups of the Hungarian political elite evaluated the situation and any further revision options differently. This led to diversion even in the changes of the security political concepts. The moderate conservative circles perceived an increasing German influence in the region and learned that in order to implement the national endeavours, it was necessary to collaborate with Berlin more intensively. At the same time, they tried to maintain a kind of balance between the German and the Western (Great Britain and United States of America) orientation while creating foreign policy. They regarded it as a positive sign that even the British government acknowledged the first Vienna Decision. As for the internal political system, these circles insisted on a constitutional parliamentary structure similar to the Western one [22].

The extreme right wing, as well as a smaller group of the 
governing party, with Prime Minister Béla Imrédy on the top who tried to attract the radical forces, basically only wanted to build on Germany. Their opinion was that the success of the revision depended only on Hitler's support; therefore they wanted to transform both the country's foreign policy and internal structure based on the Germans' example. As part of the foregoing, in February 1939, Hungary joined the Anti-Comintern Pact (the contract of Germany, Italy and Japan). Formally, this only turned against the communist endeavours, but in reality, it was a political alliance created for the collaboration of the powers preparing for war. Joining this alliance did not strengthen Hungary's security; it rather weakened that. Great-Britain condemned Hungary's action and the Soviet Union froze diplomatic relationship [23].

For the sake of preserving the constitutional parliamentary system and the internal political stability, supported by the moderate conservative political circles, the regent withdrew Imrédy and denominated Teleki as Prime Minister. One of Teleki's urgent tasks was to repel the extreme right wing. The new head of the government issued a few limiting orders in order to repel the radical forces, but he rather tried to relieve political tension compromises. In order to achieve national unity, he made efforts to highlight the common points among the moderate and extremist political circles (revision, anti-bolshevism) so that national unity could be ensured [24].

On 14 March, 1939, German troops entered the western province of Czechoslovakia and this territory was proclaimed as part of the German empire (Protectorate of Bohemia and Moravia). The Prague government capitulated unopposed and escaped to the West. The Western Powers objected to this German action, but they did not do anything to avoid it. An independent Slovakia was established from the middle, Slovakian province of Czechoslovakia. The Ukrainian nationalist political circles of the third part of the country, Subcarpathia, tried to announce this territory, too, an independent state, to which they asked for Germany's help. However, Berlin followed a go-slow policy and no other state recognised sovereignty of Subcarpathia. Having utilised this "ex lex" status, the Hungarian Army occupied this territory. The Hungarian troops acquired Subcarpathia during 3 days. There was not much fight; there were only local encounters with the leaving Czechoslovakian units and the Ukrainian nationalist paramilitary organisation, the "Carpathian Sich" [25].

With the re-annexation of Subcarpathia, a common Polish-Hungarian border was created, what considerably increased Hungary's security. A direct relationship was established with the Polish state that had strong army and which was regarded to be a regional medium power. By acquiring the Carpathian ridge, Hungary got eastern borders that could be easily protected. With the re-annexed territories, substantial raw material resources and traffic routes got back under the control of Budapest. In this territory, only $11 \%$ of the population was Hungarian, but the Ruthenian population constituting the majority also accepted Hungarian supremacy. In order to support their co-operation, they introduced various nationality rights and bilingual public administration. Teleki planned to implement autonomy with broader scale than this, however this could not be realised because of the protest Hungarian's extreme right and the outburst of the World War II [26].

The new Hungarian-Slovakian border did not have historical antecedents, because the Slovakian and Subcarpathian territories earlier always belonged to the same state: for 900 years to the Hungarian Kingdom, while between 1920 and 1939 to Czechoslovakia. The topical situation represented a serious security risk for Hungary because the temporary border line was situated directly along the public road and railway main line in the valley of River Ung. The Hungarian Army therefore occupied the western slopes of the valley of River Ung on 23 March. The Slovakian military force initiated an armed counter attack and the so called "Hungarian-Slovakian Little War" was outburst. After three days of fighting, negotiations started and on 4 April, the two parties entered into a treaty about accepting the topical border line [27].

With the split-up of Czechoslovakia, Hungary's conflict along its Northern borders had not terminated yet. Its relationship with Slovakia was also very stressful. The totalitarian Slovakia did everything to gain support from Germany and perhaps utilise it to the re-annexation of the territories being under debate with the Hungarians. Despite this fact, the primary risk factor for the Hungarian security policy became the relationship with Romania that was getting more and more tense. The nationality rights of the more than 2 million Hungarian inhabitants living in Romania were strongly limited. The Romanian government sharply rejected the Hungarian claims related to Transylvania and what was more, Romania itself claimed more Hungarian territories. In April 1939, Great-Britain guaranteed the borders of the Romanian state, what practically made a negotiation based revision impossible [28].

In summer 1939, the Hungarian government had to face a serious internal security policy problem. In the course of the Parliamentary elections, the most extremist political force, the Arrow Cross Party achieved high success. The Arrow Cross Party cleverly utilised the uncertainty, the fear, and the subsistence problems of the poorer classes what came to surface because of the fast changes taking place in the region. They gathered a considerable fan base by a demagogic programme and were elected to the Parliament as the strongest opposition party. Despite their presence in the Parliament, they kept on talking politics in the streets, organising mass demonstrations and what was more, they also applied illegal political methods. This party was also seeking contact with certain German political factors. However, due to their excessive radicalism, in addition to some financial support, Berlin did not intend to allocate them a more serious role for the time being. Berlin deepened its 
relationship with the Hungarian government instead [29].

\section{The Period of "Armed Neutrality"}

At the end of August, Germany entered into a secret treaty with the Soviet Union (Molotov-Ribbentrop Pact). They split up Central and Eastern Europe into interest spheres and agreed not to hinder each other's expansion efforts. On 1 September, the German military force attacked Poland. Slovakia joined this action. The German government also intended to use the Subcarpathian Hungarian railway line to start an attack even from the South. However, the Hungarian government rejected the related German request, for which act later on Hitler also blamed it. After the unexpectedly fast collapse of the Polish resistance, the Warsaw government retired into an exile. Utilising this event, on 17 September, Soviet troops entered East Polish territories. In this way, the failure of Poland caused a serious problem to Hungary from even two aspects. It lost its ally that it regarded the most important one and it became directly the neighbour of the Soviet Union at the area of Subcarpathia [30].

With the war against Poland, a new security policy problem also occurred: mass migration. About 110,000 Polish crossed the Hungarian border, including soldiers and civil people, even several members of the Polish government and the military leadership. The Hungarian government managed the refugees with special attention. The soldiers were disarmed and formally interned, but they ensured them free movement in reality. They made it possible for them to leave Hungary illegally with fake papers for Western Europe. They supplied the Polish remaining here with provisions, sometimes they gave work to them, community opportunities or school education, due to which the German diplomacy protested again [31].

In the existing situation, the Hungarian leadership envisaged serious threat in German politics getting in alliance with the communist Soviet Union and unscrupulous territory annexation. Therefore, Prime Minister Teleki made steps to prepare for setting up a Hungarian ghost government in the West. The Hungarian ambassador in Washington called the attention already in the previous year to the fact that in case the Western Powers also took part in formulating the destiny of Central and Eastern Europe, it was inevitable to represent the Hungarian interests, too. During World War I, only the Czech, Romanian, and Serbian emigrants had expressed their opinions publicly; nobody had outlined the Hungarian point of view in front of the Western political circles and the public. When World War II burst out, this aspect had become even more important. Furthermore, Hitler unambiguously stated that he regarded the entire region (including Hungary) to be within the German sphere of interest. In case of a German occupation similar to the ones of Czechoslovakia or Poland, only a ghost government could represent the Hungarian national sovereignty [32].

This had become urgently topical because a political crisis had developed in Romania. Germany wanted to get access to Romania's crude oil reserves in any way; therefore it announced that if it was necessary it would send troops to secure internal order. German forces could get to Romania the easiest way through Hungary. If the Hungarian government agreed to let them move over the country, it could be expected that the Germans settle down in the country and set up bases. If Budapest rejected it, a German military occupation jeopardized the country. On 6 March, Teleki instructed the president of the National Bank to transfer USD 5 million to the Hungarian embassy in Washington for the purposes of a ghost government. At the same time, he informed the ambassador in a confidential document who else were eligible to access the money in addition to the regent and the prime minister (two former prime minister, Horthy's confidante, Gyula Károlyi, István Bethlen, the president of the National Bank, Lipót Baranyai, and Hungarian ambassadors in Paris and London) [33].

In the following months, however, the international conditions substantially had changed. On 9 April, 1940, the German army entered Denmark and initiated an attack against Norway. After a fast victory, on 10 May, a new German offense was started against the Netherlands, Belgium, and France, which could not be stopped despite using the British expedition forces. In this situation, the regent and Teleki came to the conclusion that there was no sense to provoke Berlin by setting up a Hungarian ghost government in the West; instead they had to try to preserve independence by compromises in a Europe that was gradually getting under German control. On 25 May, the government took measures to return the money sent to the United States by bank transfer [34].

At the horizon of the Hungarian security politics, the Soviet Union had appeared with bigger and bigger emphasis. Josif Stalin, after occupying Poland's eastern territories, in the so called "Winter War" annexed the Southern zones of Finland. During 1940, with the help of military pressure and utilising communist forces operating in the Baltic States, he forced Estonia, Latvia and Lithuania to join. Then he sent an ultimatum to Romania in order to re-annex Northern Bukovina and Bessarabia occupied after World War I. With this, the Soviet Union pushed its borders to the West by 200 250 kilometres. Parallel to this, Moscow already showed deeper interest towards the Central and Eastern European area, and the Danube Basin, too. There were also Soviet plans to replace Subcarpathia with other territories with Hungary [35].

In summer 1940, Hungary was also focusing on Transylvania. This was the biggest detached territory, with the most Hungarian inhabitants, substantial raw material resources, and mountain border line that can be protected well, that was connected to Subcarpathia. In June 1940, the Moscow leadership raised the idea that Hungary could act for the re-annexation of Partium and Transylvania simultaneously with the Soviet territorial claims. However, the Hungarian government could not be convinced to 
collaborate with the Soviet Union, even for the sake of re-annexing Transylvania. Budapest still hoped that the territorial changes would also be approved by Great Britain (and by the USA standing behind it). It did not want to risk this opportunity with collaboration with the Bolshevik dictatorship [36].

Thus, independently from the Soviet claims, it only mentioned its territorial claims afterwards. However, Romania that had much stronger military force than the Hungarian Army rejected the Hungarian claims. The Hungarian government considered the initiation of a military action by hoping that the Romanian state withdrawing already earlier from the British territorial guarantee, which also fought with internal crisis would be forced to accept the claim. However, Germany did not watch it passively that the two small states where it acquired essential raw materials and food from had war against each other. It pushed them to start negotiations and made them agree to split up Transylvania during the Second Vienna Award (30 August 1940) passed jointly with Italy. This met the endeavours of neither party, but Hitler promised final solution only after the end of the war. With this, he pushed both states to adjust their policies more and more to the German expectations [37].

The Northern part of Transylvania was re-annexed to Hungary, while Southern Transylvania remained under Romanian supremacy. As a result of the re-annexation of Northern Transylvania, a new, double (external and internal) security policy problem occurred. Since the territory was not split up along ethnical lines, in the re-annexed Northern Transylvania, $52 \%$ of the population was Hungarian and $42 \%$ was Romanian. Consequently, almost 1 million Romanian inhabitants got under the supremacy of the Hungarian Kingdom. The entry of the Hungarian Army was not trouble free; there were aggressive actions on both sides. The Hungarian government regarded the Romanian inhabitants of the re-annexed territory unreliable. People being in leading positions in the public administration and the economy, office-holders, public servants, and the members of the law-enforcement bodies were replaced by Hungarians, just like it happened in 1920 on Romanian behalf [38].

There was similar ethnic discrimination in Southern Transylvania, where approximately 650,000 Hungarian inhabitants remained. The Hungarian politics also claimed Southern Transylvania; however, the Romanian leadership openly stated that it wanted to take back the entire Transylvania. The political tension was accompanied by several armed border incidents. The question of Transylvania remained one of the problems of the Hungarian security policy unsolved until the end of the war [39].

The Hungarian leadership tried several times to adjust its steps to the Western Powers in the buffer zone of the German and Soviet expansion. It tried to get a promise from London that in case it did not join the German or the Soviet expansion, at the end of the war the British politics would create a fair peace and would support rightful revision demands.
However, the British government did not want to commit itself for Hungary. It consistently avoided any statements that the Hungarian government could have even regarded as a blurred promise. Great Britain had the standpoint that it did not acknowledge territorial changes taking place with German collaboration (including e.g. the Vienna Awards) as being legal. Consequently, the Hungarian government could already hope for support from Berlin to its revision efforts [40].

On 27 September, Germany, Italy, and Japan signed the Tripartite Pact, in which the three world powers set out their respective territories of interest. They agreed to negotiate about the international issues and support each other if any of the countries got attacked by a new enemy. The hidden aim of the pact was to keep the USA and the Soviet Union away from the war because due to the Tripartite Pact they would have been enforced to a multi-front fight. Hitler assumed that without the USA's direct support Great Britain would be enforced to come to terms with Berlin [41].

The Hungarian government considered already on the following day that it would join the pact. Teleki's opinion was that with such a volunteer commitment it was possible to avoid a potential German aggression. Joining the pact might neutralise the efforts of the Romanian and Slovakian governments concerning the re-annexation of their territories annexed to Hungary. The prime minister hoped that after joining the pact the moderate conservative government of Budapest would be able to act with more power against the local pro-German extreme right wing opposition because Berlin would not stand out for the radicals against a government allied with it. Naturally, the Hungarian leadership also saw the risks of joining the pact. Signing the Tripartite Pact substantially limited the sweep of the Hungarian foreign politics; it made it compulsory to the country to show solidarity towards the German endeavours. It was also obvious that in case of the Western Powers' victory, Hungary, being Berlin's ally, would again get in the losers' camp just like after World War I [42].

However, several factors urged for the joining of the pact. The German government wished to send a considerable military force to Romania through Hungary again. According to an official announcement, the so called "study troops" arrived for the training of the Romanian military force. In reality, they wanted to secure the crude oil resources essential for the Germans. They planned to cross Hungarian territories. This had the risk that the Germans might stay in Hungary, i.e. they would build out bases with reference to supplying their troops while crossing the country. If, on the other hand, the Hungarian government would reject letting the troops cross the country, Hitler might order the occupation of the Hungarian territories. Slovakia and Romania also announced their intent to join the Tripartite Pact. These two governments hoped that after signing the pact, Berlin would support their steps to hinder the Hungarian revision. Consequently, Hungary might lose the territories re-annexed earlier. That was why the Hungarian 
diplomacy regarded already not only the joining of the pact essential, but also the fact that Hungary should enter the alliance first from among the rivalling small states of the region [43].

Certain internal political affairs also caused security problems to Hungary. Imrédy, leaving the governing party, established a new, strong extreme right wing cluster that could count on substantial German support. On 7 October, a miners' strike burst out which due to the manipulation of the arrow cross party had become country-wide during a few weeks. The arrow cross party hoped that stopping the coal shipments to Germany would push Hitler to interfere in Hungary. Finally, the government recovered production, but every event similar to that jeopardized the existing constitutional system [44].

Finally, the Hungarian government chose to "rescue forward", so on 20 November, it signed the joining agreement to the Tripartite Pact. However, Hungary and later on the joining small states were only regarded to be second-rank allies. While they had to undertake solidarity and collaboration with the rest of the participants, they had a say how to formulate the alliance's strategy only to a limited extent: the world powers only listened to their opinion in cases in which they were also directly involved. By all means, with its joining, the Hungarian government still could not feel safe. In this region, Hitler regarded Romania as its primary ally. On the one hand, Bucharest supplied him with the most important raw material, oil that was indispensable in a mechanic war. On the other hand, the internal system of Romania, and its extreme right wing dictatorship being built were much closer to the German system than the Hungarian constitutional parliamentary conditions. Lastly, the Romanian leadership seemed to be much more willing to support the German ideas than the Hungarian government, which rejected Berlin's requests from time to time [45].

In turn with their role played in the Second Vienna Award, the Germans soon stepped forward with newer requests. They urged that Hungary increased significantly its supply of raw materials and food. They interfered in the Hungarian internal affairs policy and required to ban the legally operating left wing organisations (including the Social Democratic Party). They tried to force a newer pact on Hungary, which would have allowed for them to take the Hungarian press and mass communication under their control. The Hungarian government mostly fulfilled the economic requests; however it rejected the political type of efforts. The Hungarian government's behaviour, namely that it fulfilled the German expectations only reluctantly and just in part, resulted in high dissatisfaction in the German leading circles. On 23 November, Minister of propaganda, Joseph Goebbels wrote in his diary that the Hungarian political leadership was unambiguously anti-German. It did not understand the "word of the new times", so it should be replaced by radical political forces that support the German efforts much more [46].

There was a separate debate about the situation of the
German minority living in Hungary. From the German minority that got under the influence of the national-socialists, Berlin expected to try to push the Hungarian government from inside, and in the course of this to find connections to the Hungarian extreme right wing forces, too. Germany claimed that Budapest awarded special rights to the population having German nationality, what already infringed the Hungarian state's sovereignty. The Hungarian government did not want to get confronted; therefore theoretically it accepted Berlin's conditions and promised special autonomy to the German minority. However, in practice, it made efforts to limit the enforcement of these minority rights [47].

Hungary was looking for a political counterbalance against the German pressure. It made endeavours to intensify its relationship with Yugoslavia. Belgrade also intended to have balance in foreign politics; it did not want to provoke Germany, but tried to preserve its British relationships. In December 1940, after short negotiations, the Treaty of Eternal Friendship of Hungary and Yugoslavia was entered into force as a result of German expansion. The two countries committed themselves to collaborate and declared that they acknowledge minority rights. In the treaty, Hungary maintained its territorial claim for Southland that was inhabited by Hungarians, but declared that it wanted to settle territorial issues via interstate bilateral negotiations, not by force. The Treaty of Eternal Friendship mutually cut out the security policy pressure being earlier present on behalf of the other country and strengthened the international positions of both states. The Western Powers and in general, the European neutral states appreciated this step. However, Germany expressed its deprecation that the Hungarian government tried to follow a specific policy regardless of Berlin [48].

At the beginning of 1941, newer, large German troop transportations started towards Romania. The Romanian government asked for German help to restrain internal political turmoil and to pull down the iron guard riot. The repeated transit of the troops and the open interfering into the Romanian internal affairs policy were regarded by the Hungarian regent and the people surrounding him as serious threat, therefore the idea of setting up a Hungarian ghost government in the West came up again. Regent Horthy did not want to go abroad even in case of a German occupation that was why the name of István Bethlen former Prime Minister was raised as the head of the ghost government [49].

The moderate, conservative politician was regarded even in Great Britain as a fluent person. The British government did not promise, however, that it would recognise the ghost government headed by Bethlen in the same way as the Czechoslovakian one. It had not changed either that Hungary did not get any encouragement concerning the issue that at the end of the war Great Britain would stand for rearranging the borders by taking into account ethnic aspects. The plan related to the establishment of a Hungarian ghost government had failed again. Because of the uncertain 
British reception and Berlin's expected reactions, the Hungarian leadership chose the "lesser evil", i.e. further collaboration with the Germans in order not to risk occupation [50].

\section{Hungary Entered the War}

In spring 1941, Germany was already preparing for attacking the Soviet Union. In order to do that, it wanted to keep the Balkans, Yugoslavia and Bulgaria under control and planned to occupy Greece that had been Great Britain's ally. In March, Bulgaria voluntarily signed the Tripartite Pact. However, the Yugoslavian government could only be persuaded by considerable pressure to join it. After its joining, however, a putsch burst out in Belgrade and a new, pro-English government rose into power. Hitler immediately ordered that the German military force commence an attack against Yugoslavia. Since Germany was pushed for time, in the Yugoslavian campaign, Berlin required an active participation from Italy, Bulgaria and Hungary, too [51].

The Hungarian government got into a difficult situation. If it accepted the German claim, it would infringe the Treaty of Eternal Friendship, lose its only ally in the region and confront with Great Britain. If it turned against Hitler's claim, the German military force would occupy Hungary in the same way as Yugoslavia or raise an extreme right wing government into power that would readily fulfil each and every wish of Berlin. In such a case, the Hungarians in Southland would also get under the supremacy of Germany or Romania. Romania and Slovakia would get back again the earlier re-annexed territories [52].

The Hungarian government did not dare and did not want to openly confront Germany; it was only willing to collaborate under certain conditions. It stated that the Hungarian Army would only cross the Yugoslavian border, if the Hungarians living there suffered atrocities or if the Yugoslavian Kingdom got disrupted as a result of the Croatians' detachment and was not able to guarantee meeting the clauses of the Treaty of Eternal Friendship. In the meantime, Prime Minister Teleki desperately tried to convince the British government that Budapest had no choice, thus it had to surrender to German pressure. London, however, reacted repulsively and warned Hungary that it could expect a British declaration of war if it collaborated with Hitler. Teleki felt that his country inevitably drifted towards the war. Under the weight of moral responsibility, he collapsed and committed suicide [53].

His legal successor László Bárdossy initially made efforts to meet the requirements announced by Teleki. On 6 April, the German attack was started, as a result of which, on 10 April, Croatia declared its independence. With this, the former Yugoslavian Kingdom got disrupted. The Hungarian Army only crossed the border after that and re-occupied the territories that earlier belonged to Hungary, where mostly Hungarians lived. Great Britain terminated its diplomatic relationship with Hungary. However, despite earlier warning, no declaration of war took place at that time, because the British government could also see that Budapest acted under German pressure [54].

The entering Hungarian Army did not clash with the main forces of the Yugoslavian military force, because the Belgrade government already withdrew them from the Hungarian inhabited territories. However, there were several local clashes taking place with the Serbian nationalist semi-military troops, the chetniks. The Hungarian military public administration introduced at the occupied territories distrustfully adjusted itself to the local Serbian population. Approximately 10,000 Serbian families were deported from Southland who were then, after 1920, settled down by the Serbian government in Hungarian inhabited territories to change the ethnic composition of the area. This hostile relationship led to uncertainty and instability even later on, so it led to guerrilla attacks on behalf of Serbia and atrocities against the Serbian population on behalf of Hungary [55]

As a result of the German occupation of Yugoslavia, Hungary got into a dangerous vacuum situation from the point of view of security politics. Its Western relationships, except for the USA, terminated. Its relationship with its neighbouring countries kept on being stressed despite of the fact that they belonged to the same alliance system. Dictatorship was built out in each neighbouring state (Slovakia, Romania, Serbia and Croatia) and German troops were staying at the territories of each of them, which meant considerable pressure and a must for adaptation to the Hungarian government. Although the Soviet Union was not preparing for an attack against Hungarian territories, it obviously represented a security risk with its Bolshevik system, and communist ideas. Hungary was not yet participating in the war, but under such circumstances, very little chance remained for it to preserve its military neutrality [56].

On 22 June, 1941, Germany commenced an attack against the Soviet Union. The Hungarian leadership was glad that with this the risk represented by communism would terminate. However, they did not want to enter this war actively. The security problems caused by the weakness of the Hungarian Army, the economic difficulties, and the social stresses drove them to maintain neutrality. Hungary did not have any territorial claims towards the Soviet Union, thus it had no reason to enter the war. On 23 June, in order to express solidarity with Germany, Prime Minister Bárdossy terminated diplomatic relationship with the Soviet Union, but no military action was taken [57].

However, extremely high external and internal pressure was on the Hungarian government to participate in the attack. This time, Hitler did not request Hungary officially to collaborate, because in turn he had had to make a new promise to support the further Hungarian revision efforts. But the German military leadership regarded it necessary for the Hungarians to participate; therefore they tried to push the heads of the Hungarian Army that Hungary voluntarily joins 
the campaign. The German generals, the members of the German economic and cultural organs operating in Hungary, the German intelligence service and the SS agents tried to influence the Hungarian politicians with similar promises. At the same time, they threatened them that in case the Hungarian leadership kept on remaining passive, they could not count on the re-annexation of the Hungarian territories being still under foreign supremacy, or instead, Berlin might start to support the anti-Hungarian Slovakian and Romanian territorial endeavours. The leadership of the radical organisation representing the German minority in Hungary ("Volksbund der Deutschen in Ungarn" - Folk Union of Germans in Hungary) spread the same. The Hungarian extreme right wing also made a similar propaganda, which sharply criticised the behaviour of the government [58].

The military staff of the Army did everything they could to make Regent Horthy and the government to enter the war. They argued that the German troops would surely defeat the Red Army within a few months. If Hungary entered the war, Germany would supply the Hungarian Army with modern weapons. The German government would surely be grateful for the collaboration and in this way it would also allow for the re-annexation of the still missing Hungarian territories: Southern Transylvania, and the Banat being under German occupation (earlier belonged to Yugoslavia). This tense situation was resolved by an event that remained uncleared until this day. On 26 June, 3 unidentified airplanes did a bomb attack against a North-Eastern Hungarian town, Kosice. The Hungarian Army's leadership, without in-depth investigation, blamed the Soviet Union for this attack. With reference to this, they convinced the astonished regent Horthy to take military measures [59].

Prime Minister Bárdossy did not protest against it, did not make any diplomatic steps in order to clarify the case, and did not try to maintain neutrality. By surrendering to the political pressure, already he himself also urged for entering the war. Exceeding his scope of authority as the head of the government, on the following day, on 27 June, he announced in the Parliament that there was a state of war between Hungary and the Soviet Union. According to the Constitution, such a decision could only have been passed by the Parliament, but the prime minister did not leave any choice for the members of the Parliament. In the following days, the Hungarian Army also joined the fights against the Red Army, what was accompanied by random Soviet air attacks against Hungarian territories and considerable Hungarian front losses [60].

However, from the point of view of security policy, Hungary's entering the war did not primarily serve the rollback of the Soviet troops, and the weakening of the Bolshevik system; it was done by the German military force even without the Hungarian Army. With this step, the real aim for Hungary was to regain Germany's trust in order to keep the re-annexed territories and have hope for continuing the revision. Consequently, the announcement of the state of war was rather a message to Berlin instead of a message to Moscow. Most of the Hungarian political elite came to the conclusion that because already each German ally had joined the attack, including the rivalling neighbouring states (Slovakia, Romania and Croatia); there was no sense for Hungary to turn against the German expectations alone, without any allies. Especially, because everybody expected fast German victory, even most of the Western experts [61].

The case of Yugoslavia demonstrated it well what a threat Germany represented if somebody turned against it. Hungary could not count on the West's real support. Even Great Britain only defined expectations that the Hungarian government should not fulfil Berlin's requests, but in turn it provided neither support, nor gave any promise. The Hungarian extreme right wing only waited for the opportunity to gain power with German support. Consequently, the government first of all took into account the short term aspects for its decisions and counted much less with the longer term impacts of the war, the economic burdens, the losses, and the retorsions that could be expected if the Western Powers or the Soviet Union won. Hungary became an actor in the war. Although the Hungarian political elite basically only supported the fight against the Soviet Union, they could not select their counterparts. In the coming months, Hungary got into opposition with the Western Powers, too. Upon Soviet request, the British government declared war against Hungary, while Bárdossy, surrendering to Berlin's pressure, exceeding his scope of authority again, announced the state of war also against the United States on 12 December [62].

During these months, another aspect appeared, in which the Hungarian government envisioned increasingly higher security political risk and what was called "Double Little Entente". Upon the initiation of the Slovakian government, in 1941, political and economic negotiations were commenced between Slovakia, Romania and the new Croatian State. They aimed at closer co-operation and discussing their steps against Hungary. With this, it can be said, that they continued the policy of the former Little Entente. At the same time, the Czechoslovakian and Yugoslavian governments that escaped to London and were acknowledged by the British government, as well as the Romanian emigrant politicians staying in Great-Britain also started negotiations, with similar goal. The Hungarian leadership was afraid that the joint action of the neighbouring states upon German victory, while that of the emigrant politicians upon Western victory could push Hungary into a not rightful peace treaty just like the Trianon one [63].

Consequently, at the end of 1941, the Hungarian government found itself in an extremely specific security policy situation. It kept on being in a tense situation with its neighbours, with whom it fought on the same side. It had claims neither towards the Soviet Union, nor towards the Western Powers with whom it entered into a state of war. Its security was mostly jeopardized by Germany that was 
officially its ally and to whom it increasingly more and more committed itself in practice.

\section{Conclusions}

The preferences of the Hungarian security policy did not change substantially between the two World Wars. Between 1938 and 1941, however, there were significant shifts in the preferences. The Little Entente surrounding the country seized to exist. From among the neighbours, instead of Czechoslovakia, Romania became the most dangerous rival. The earlier supporting world power, Italy, lost its influence in the area. Germany that was regarded to be an economic partner first became the main supporter of the Hungarian revision endeavours, but soon it changed to be the most dangerous factor with respect to Hungarian independence. Hungary did not have any direct conflict with the Soviet Union until the war burst out. However, having surrendered to German pressure, the Hungarian government joined the war against the Soviet Union in summer 1941 and with this step it made a neighbouring world power its enemy for a long term. Regent Horthy and the people surrounding him, as well as the dominant groups of the political elite considered the Western orientation important. Until the summer of 1940, they tried to obtain support from Great Britain or at least its understanding towards the Hungarian endeavours; however they got no encouragement from London. Consequently, upon the request of Germany that gained control over the continent they terminated the Western relationships.

All in all, the Hungarian security policy had a complex idea based on a realistic evaluation of the situation concerning the closer Central and Eastern European region. However, with respect to the wider European horizon, it assessed the situation incorrectly and adjusted its steps to expectations that were not justified during the World War. The Hungarian governing elite, in the narrow margin being available for them - because of the risk of German occupation, preferred the short term security policy aspects as opposed to the country's longer term interests.

\section{REFERENCES}

[1] Ormos, M., Majoros, I. Európa a nemzetközi küzdőtéren [Europe in the International Arena]. Osiris, Budapest, 2003, 257; Fisher, H. H. The Famine in Soviet Russia, 1919-1923. Macmillan, New York, 1927, 25.

[2] Kontler, L. A History of Hungary. Atlantisz Publishing House, Budapest, 2009, 336-337; Zeidler, M. Ideas on Territorial Revision in Hungary, 1920-1945. Social Science Monographs, Boulder, 2007, 59-61.

[3] Dreisziger, N. Hungary and the Second World War. In: Dreisziger, N. (ed.), Hungary in the Age of Total War, 19381948, pp. 3-24. East European Monographs, Boulder, 1998. 6; Zeidler, M. Ideas on Territorial Revision in Hungary, 19201945. Social Science Monographs, Boulder, 2007, 48-50, 9698.
[4] Cornelius, D. S. Hungary in World War II: Caught the Cauldron. Fordham University Press, New York, 2011, 33-44; Kontler, L. A History of Hungary. Atlantisz Publishing House, Budapest, 2009, 352-354.

[5] Romsics, I. Hungary in the Twentieth Century. Corvina, Osiris, Budapest, 2010, 194-195.

[6] Bán, A. D. Hungarian-British Diplomacy, 1938-1941. Frank Cass, Portland, London, 2004, 13; Horthy, N. A Life for Hungary: Memoirs. Ishi Press International, New York, Tokio, 2011,135 .

[7] Ormos, M., Majoros, I. Európa a nemzetközi küzdőtéren [Europe in the International Arena]. Osiris, Budapest, 2003, 316; Romsics, I. Hungary in the Twentieth Century. Corvina, Osiris, Budapest, 2010, 192-193.

[8] Cornelius, D. S. Hungary in World War II: Caught the Cauldron. Fordham University Press, New York, 2011, 54-55.; Gulyás, L. A Horthy-korszak külpolitikája. A revíziós sikerek: A Felvidék és Kárpátalja visszatérése, 1937-1939 [The Foreign Policy of the Horthy Era. Revision Successes: The Return of Hungarian Upperland and Subcarpathia, 19371939]. Attraktor, Máriabesnyő, 2016, 15-16.

[9] Dreisziger, N. Hungary and the Second World War. In: Dreisziger, N. (ed.), Hungary in the Age of Total War, 19381948, pp. 3-24. East European Monographs, Boulder, 1998, 6-7.

[10] Macartney, C. A. October Fifteenth: A History of Modern Hungary 1929-1945, Vol. I. Edinburgh University Press, Edinburgh, 1961, 210-211.

[11] Tilkovszky, L. The Late Interwar Years and World War II. In: Sugar, P. F. (gen. ed.), A History of Hungary, pp. 339-355. Indiana University Press, Bloomington, Indianapolis, 1994, 339; Cornelius, D. S. Hungary in World War II: Caught the Cauldron. Fordham University Press, New York, 2011, 70-72.

[12] Sakmyster, T. Hungary's Admiral on Horseback: Miklós Horthy, 1918-1944. East European Monographs, Boulder, 1994, 207-208.

[13] Bán, A. D. Hungarian-British Diplomacy, 1938-1941. Frank Cass, Portland, London, 2004, 26-27.; Kershaw, I. Hitler, 1936-1945: Nemezis [Hitler, 1936-1945: Nemesis]. Szukits, Szeged, 2000, 110-113.

[14] Sakmyster, T. Hungary's Admiral on Horseback: Miklós Horthy, 1918-1944. East European Monographs, Boulder, 1994, 214.

[15] Kontler, L. A History of Hungary. Atlantisz Publishing House, Budapest, 2009, 382; Hill, L. E. (ed.) Die Weizsäcker Papiere, 1933-1950. Propyläen, Frankfurt, 1974, 138; Horthy, N. A Life for Hungary: Memoirs. Ishi Press International, New York, Tokio, 2011, 255.

[16] Sallai, G. Az első bécsi döntés [The First Vienna Award]. Osiris, Budapest, 2002. 58-59; Bán, A. D. Hungarian-British Diplomacy, 1938-1941. Frank Cass, Portland, London, 2004, 37-38.

[17] Gulyás, L. A Horthy-korszak külpolitikája. A revíziós sikerek: A Felvidék és Kárpátalja visszatérése, 1937-1939 [The Foreign Policy of the Horthy Era. Revision Successes: The Return of Hungarian Upperland and Subcarpathia, 19371939]. Attraktor, Máriabesnyő, 2016, 88-91. 
[18] Romsics, I. Hungary in the Twentieth Century. Corvina, Osiris, Budapest, 2010, 197; Dombrády, L. A legfelsőbb hadúr és hadserege [The Supreme Warlord and his Army]. Kairosz, Budapest, 2012, 185.

[19] Ablonczy, B. Pál Teleki (1874-1941): The Life of a Contraversial Hungarian Politician. Social Science Monographs, Boulder, 2006, 159-160; Cornelius, D. S. Hungary in World War II: Caught the Cauldron. Fordham University Press, New York, 2011, 89-93.

[20] Horthy, N. A Life for Hungary: Memoirs. Ishi Press International, New York, Tokio, 2011, 170; Poszpelov, P. (ed.), Dokumenti i matyeriali po isztorii szovjetszkocsehoszlovackih otnosenyij [Documents and materials about the History of Soviet-Czechoslonvakian relations]. Vol. III. Nauka, Moszkva, 1978. 484-485, 515-517.

[21] Macartney, C. A. October Fifteenth: A History of Modern Hungary 1929-1945, Vol. I. Edinburgh University Press, Edinburgh, 1961, 300-301; Gulyás, L. A Horthy-korszak külpolitikája. A revíziós sikerek: A Felvidék és Kárpátalja visszatérése, 1937-1939 [The Foreign Policy of the Horthy Era. Revision Successes: The Return of Hungarian Upperland and Subcarpathia, 1937-1939]. Attraktor, Máriabesnyő, 2016, 140.

[22] Ormos, M. Közép-Európa: Volt? Van? Lesz? [Central Europe: Was it? Is it? Will it?]. Napvilág, Budapest, 2007, 186; Dreisziger, N. Hungary and the Second World War. In: Dreisziger, N. (ed.), Hungary in the Age of Total War, 1938 1948, pp. 3-24. East European Monographs, Boulder, 1998. 7.

[23] Bán, A. D. Hungarian-British Diplomacy, 1938-1941. Frank Cass, Portland, London, 2004, 57; Tilkovszky, L. The Late Interwar Years and World War II. In: Sugar, P. F. (gen. ed.), A History of Hungary, pp. 339-355. Indiana University Press, Bloomington, Indianapolis, 1994, 340.

[24] Czettler, A. Teleki Pál és a magyar külpolitika, 1939-1941 [Pál Teleki and the Hungarian Foreign Policy, 1939-1941]. Kairosz, Budapest, 2008，32; Sakmyster, T. Hungary's Admiral on Horseback: Miklós Horthy, 1918-1944. East European Monographs, Boulder, 1994, 231.

[25] Fenyo, M. D. Hitler, Horthy and Hungary German-Hungarian Relations, 1941-1944. Yale University Press, New Haven, London, 1972, 6-7; Körner-Lakatos, E. Horthy Miklós: Bruchstücke und Ergänzungen. Octopus, Münster, 2011, 319320.

[26] Romsics, I. Hungary in the Twentieth Century. Corvina, Osiris, Budapest, 2010, 199; Macartney, C. A. October Fifteenth: A History of Modern Hungary 1929-1945, Vol. I. Edinburgh University Press, Edinburgh, 1961, 330.

[27] Janek, I. Szlovák-magyar kapcsolatok, 1939-1944 [SlovakHungarian Relations, 1939-1944]. Pécsi Tudományegyetem, Pécs, 2009, 72-75.; Ablonczy, B. Pál Teleki (1874-1941): The Life of a Contraversial Hungarian Politician. Social Science Monographs, Boulder, 2006, 179-180.

[28] Macartney, C. A. October Fifteenth: A History of Modern Hungary 1929-1945, Vol. I. Edinburgh University Press, Edinburgh, 1961, 355-356.

[29] Kontler, L. A History of Hungary. Atlantisz Publishing House, Budapest, 2009, 384; Cornelius, D. S. Hungary in World War II: Caught the Cauldron. Fordham University Press, New York, 2011, 110-111.
[30] Ormos, M., Majoros, I. Európa a nemzetközi küzdőtéren [Europe in the International Arena]. Osiris, Budapest, 2003, 408; Nebelin, M. Deutsche Ungarnpolitik 1939-1941. Leske, Budrich, Opladen, 1989, 66.

[31] Sakmyster, T. Hungary's Admiral on Horseback: Miklós Horthy, 1918-1944. East European Monographs, Boulder, 1994, 238-239; Fenyo, M. D. Hitler, Horthy and Hungary German-Hungarian Relations, 1941-1944. Yale University Press, New Haven, London, 1972, 7-8.

[32] Pelényi, J. The Secret Plan for a Hungarian Government in the West at the Outbreak of World War II. The Journal of Modern History, Vol. 36, No. 2, 1964, 171-177.

[33] Hillgruber, A. Hitler, König Carol und Marschall Antonescu. Die deutsch-rumänischen Beziehungen 1938-1944. Steiner, Wiesbaden, 1954, 70-71.; Borbándi, Gy. A Teleki-Pelényi terv nyugati magyar ellenkormány létesítésére [TelekiPelényi Plan for the Eshtablishnemt of a Hungarian Counter-government in the West]. Új Látóhatár. Vol. 17, No. 2, 1966, 156-167.

[34] Borbándi, Gy. A Teleki-Pelényi terv nyugati magyar ellenkormány létesítésére [Teleki-Pelényi Plan for the Eshtablishnemt of a Hungarian Counter-government in the West]. Új Látóhatár. Vol. 17, No. 2, 1966, 156-167.; Pelényi, J. The Secret Plan for a Hungarian Government in the West at the Outbreak of World War II. The Journal of Modern History, Vol. 36, No. 2, 1964, 171-177.

[35] Kolontári, A. Magyar-szovjet diplomáciai, politikai kapcsolatok, 1920-1941 [Hungarian-Soviet Diplomatic and Political Relations, 1920-1941]. Napvilág, Budapest, 2009, 306-307; Halecki, O. A nyugati civilizáció peremén [At the Periphery of Western Civilization]. Osiris, Századvég, Budapest, 2000, 298-299.

[36] Horthy, N. A Life for Hungary: Memoirs. Ishi Press International, New York, Tokio, 2011, 179-180; Ormos, M., Majoros, I. Európa a nemzetközi küzdőtéren [Europe in the International Arena]. Osiris, Budapest, 2003, 432-434.

[37] Körner-Lakatos, E. Horthy Miklós: Bruchstücke und Ergänzungen. Octopus, Münster, 2011, 332-333; Dombrády, L. A legfelsőbb hadúr és hadserege [The Supreme Warlord and his Army]. Kairosz, Budapest, 2012, 202-203.

[38] Bán, A. D. Hungarian-British Diplomacy, 1938-1941. Frank Cass, Portland, London, 2004, 98-99.; Cornelius, D. S. Hungary in World War II: Caught the Cauldron. Fordham University Press, New York, 2011, 129-136.

[39] Ablonczy, B. Pál Teleki (1874-1941): The Life of a Contraversial Hungarian Politician. Social Science Monographs, Boulder, 2006, 214-216; L. Balogh, B. Küzdelem Erdélyért: A magyar-román viszony és a kisebbségi kérdés 1940-1944 között [Fight for Transylvania: The Hungarian-Romanian Relationship and the Minority Issue between 1940 and 1944]. Akadémiai, Budapest, 2013. $152-153$.

[40] Bán, A. D. Hungarian-British Diplomacy, 1938-1941. Frank Cass, Portland, London, 2004, 100-101; Ablonczy, B. Pál Teleki (1874-1941): The Life of a Contraversial Hungarian Politician. Social Science Monographs, Boulder, 2006, 202205.

[41] Halmosy, D. Nemzetközi szerződések 1918-1945 [International treaties, 1918-1945]. Közgazdasági és Jogi Pub., Budapest, 1983, 500-503; Hill, L. E. (ed.), Die Weizsäcker Papiere, 1933-1950. Propyläen, Frankfurt, 1974, 212-218. 
[42] Dombrády, L. A legfelsőbb hadúr és hadserege [The Supreme Warlord and his Army]. Kairosz, Budapest, 2012, 221-222; Macartney, C. A. October Fifteenth: A History of Modern Hungary 1929-1945, Vol. I. Edinburgh University Press, Edinburgh, 1961, 436-440.

[43] Hillgruber, A. Hitler, König Carol und Marschall Antonescu. Die deutsch-rumänischen Beziehungen 1938-1944. Steiner, Wiesbaden, 1954, 96-98; Ablonczy, B. Pál Teleki (18741941): The Life of a Contraversial Hungarian Politician. Social Science Monographs, Boulder, 2006,

[44] Ablonczy, B. Pál Teleki (1874-1941): The Life of a Contraversial Hungarian Politician. Social Science Monographs, Boulder, 2006, 226-228.

[45] Bán, A. D. Hungarian-British Diplomacy, 1938-1941. Frank Cass, Portland, London, 2004, 106-107.; Dreisziger, N. Hungary and the Second World War. In: Dreisziger, N. (ed.), Hungary in the Age of Total War, 1938-1948, pp. 3-24. East European Monographs, Boulder, 1998, 7-8.

[46] Goebbels, J. Die Tagebücher von Joseph Goebbels: Sämtliche Fragmente. Frölich, E. (ed.), Vol. I. Saur Verlag, München, 1987, 406-407; Macartney, C. A. October Fifteenth: A History of Modern Hungary 1929-1945, Vol. I. Edinburgh University Press, Edinburgh, 1961, 460.

[47] Cornelius, D. S. Hungary in World War II: Caught the Cauldron. Fordham University Press, New York, 2011, 131132; Macartney, C. A. October Fifteenth: A History of Modern Hungary 1929-1945, Vol. I. Edinburgh University Press, Edinburgh, 1961, 456-457.

[48] Kontler, L. A History of Hungary. Atlantisz Publishing House, Budapest, 2009, 386; Romsics, I. Hungary in the Twentieth Century. Corvina, Osiris, Budapest, 2010, 201.

[49] Sakmyster, T. Hungary's Admiral on Horseback: Miklós Horthy, 1918-1944. East European Monographs, Boulder, 1994, 253-255.

[50] Czettler, A. Teleki Pál és a magyar külpolitika 1939-1941 [Pál Teleki and the Hungarian Foreign Policy, 1939-1941]. Kairosz, Budapest, 2008, 246-247; Eckhardt, T. Visszaemlékezések, 1941-1943 [Memoirs, 1941-1943]. Kádár Lynn, K. (ed.), L’Harmattan, Budapest, 2008, 109-111.

[51] Megargee, G. P. Inside Hitler's High Command. University Press of Kansas, Lawrence, 2000, 100-101; Cornelius, D. S. Hungary in World War II. Caughtthe Cauldron. Fordham University Press, New York, 2011, 140-141.

[52] Cornelius, D. S. Hungary in World War II: Caught the Cauldron. Fordham University Press, New York, 2011, 141-
143; Fenyo, M. D. Hitler, Horthy and Hungary GermanHungarian Relations, 1941-1944. Yale University Press, New Haven, London, 1972, 9-11.

[53] Nebelin, M. Deutsche Ungarnpolitik 1939-1941. Leske, Budrich, Opladen, 1989, 168; Ablonczy, B. Pál Teleki (18741941): The Life of a Contraversial Hungarian Politician. Social Science Monographs, Boulder, 2006, 229.

[54] Dombrády, L. A legfelsőbb hadúr és hadserege [The Supreme Warlord and his Army]. Kairosz, Budapest, 2012, 229-230; Kontler, L. A History of Hungary. Atlantisz Publishing House, Budapest, 2009, 387.

[55] Zeidler, M. Ideas on Territorial Revision in Hungary, 19201945. Social Science Monographs, Boulder, 2007, 279.

[56] Romsics, I. Hungary in the Twentieth Century. Corvina, Osiris, Budapest, 2010, 204.

[57] Horthy, N. A Life for Hungary: Memoirs. Ishi Press International, New York, Tokio, 2011, 190; Macartney, C. A. October Fifteenth: A History of Modern Hungary 1929-1945, Vol. II. Edinburgh University Press, Edinburgh, 1961, 24-27.

[58] Olasz, L. A kormányzóhelyettesi intézmény története, 19411944 [History of the Institution of Deputy-Regent, 19411944]. Akadémiai, Budapest, 2007, 91-92; Fenyo, M. D. Hitler, Horthy and Hungary German-Hungarian Relations, 1941-1944. Yale University Press, New Haven, London, 1972, $18-19$.

[59] Cornelius, D. S. Hungary in World War II: Caught the Cauldron. Fordham University Press, New York, 2011, 148149; Macartney, C. A. October Fifteenth: A History of Modern Hungary 1929-1945, Vol. II. Edinburgh University Press, Edinburgh, 1961, 29-31.

[60] Romsics, I. Hungary in the Twentieth Century. Corvina, Osiris, Budapest, 2010, 204-205; Horthy, N. A Life for Hungary: Memoirs. Ishi Press International, New York, Tokio, 2011, 191.

[61] Sakmyster, T. Hungary's Admiral on Horseback: Miklós Horthy, 1918-1944. East European Monographs, Boulder, 1994, 265-266.

[62] Cornelius, D. S. Hungary in World War II: Caught the Cauldron. Fordham University Press, New York, 2011, 179181; Horthy, N. A Life for Hungary: Memoirs. Ishi Press International, New York, Tokio, 2011, 193-194.

[63] Olasz, L. A kormányzóhelyettesi intézmény története, 19411944 [History of the Institution of Deputy-Regent, 19411944]. Akadémiai, Budapest, 2007, 97-98. 